\title{
Direct Protonation of the W-H Bonds of Bis(pentamethylcyclopentadienyl)tungsten Dihydride
}

\author{
Gerard Parkin and John E. Bercaw* \\ A. A. Noyes Laboratory of Chemical Physics, California Institute of Technology, Pasadena, California 91125, U.S.A.
}

Protonation of $\left(\mathrm{C}_{5} \mathrm{Me}_{5}\right)_{2} \mathrm{WH}_{2}$ to give $\left[\left(\mathrm{C}_{5} \mathrm{Me}_{5}\right)_{2} \mathrm{WH}_{3}\right]+$ is proposed to occur by attack at both $\mathrm{W}-\mathrm{H}$ bonds rather than by direct attack at the $\mathrm{d}^{2}$ metal centre.

Protonation reactions of $\mathrm{d}^{n}(n \geqslant 2)$ transition metal complexes are generally believed to occur by direct attack at the metal centre. The dihydride, $\left(\mathrm{C}_{5} \mathrm{Me}_{5}\right)_{2} \mathrm{WH}_{2},{ }^{1}$ is readily, and reversibly, protonated by a variety of acids $\left(e . g . \mathrm{HBF}_{4} \cdot \mathrm{Et}_{2} \mathrm{O}\right.$, $\mathrm{HCl}_{\mathrm{aq}}$, and $\left.\left[\mathrm{Me}_{3} \mathrm{NH}\right]\left[\mathrm{BPh}_{4}\right]\right)$ to give the trihydride cation, $\left[\left(\mathrm{C}_{5} \mathrm{Me}_{5}\right)_{2} \mathrm{WH}_{3}\right]+[$ equation (1)].

$$
\left(\mathrm{C}_{5} \mathrm{Me}_{5}\right)_{2} \mathrm{WH}_{2} \underset{\mathrm{OH}^{-}}{\stackrel{\mathrm{H}^{+}}{\leftrightarrows}}\left[\left(\mathrm{C}_{5} \mathrm{Me}_{5}\right)_{2} \mathrm{WH}_{3}\right]^{+}
$$

Some rather unexpected features of the stereochemistry of this protonation have been revealed by examination of the addition of $\mathrm{D}^{+}$to $\left(\mathrm{C}_{5} \mathrm{Me}_{5}\right)_{2} \mathrm{WH}_{2}$. Treatment of a suspension of $\left(\mathrm{C}_{5} \mathrm{Me}_{5}\right)_{2} \mathrm{WH}_{2}$ in $\mathrm{D}_{2} \mathrm{O}$ with a solution of $\mathrm{DCl} / \mathrm{D}_{2} \mathrm{O}$ initially (within $1 \mathrm{~min}$ ) affords a mixture of isomers of $\left[\left(\mathrm{C}_{5} \mathrm{Me}_{5}\right)_{2} \mathrm{~W}(\mathrm{H})_{2}(\mathrm{D})\right]^{+}$: that with the deuterium occupying the central position, $\left[\left(\mathrm{C}_{5} \mathrm{Me}_{5}\right)_{2} \mathrm{~W}(\mathrm{H})(\mathrm{D})(\mathrm{H})\right]^{+}$predominates $(c a$. $90 \%$ ) [equation (2)], with a much smaller fraction of the laterally deuteriated isotopomer, $\left[\left(\mathrm{C}_{5} \mathrm{Me}_{5}\right)_{2} \mathrm{~W}(\mathrm{H})(\mathrm{H})(\mathrm{D})\right]^{+}$ (ca. 10\%). Subsequent exchange of the lateral and central ligands occurs over a period of several hours [equation (2)], accompanied by further incorporation of deuterium from the solvent.

Possible pathways for the protonation of $\left(\mathrm{C}_{5} \mathrm{Me}_{5}\right)_{2} \mathrm{WH}_{2}$ with $\mathrm{D}^{+}$are shown in Scheme 1. On the basis of ground state orbital control arguments, an electrophile would be predicted to attack initially at the HOMO. A qualitative MO diagram for $\left(\mathrm{C}_{5} \mathrm{Me}_{5}\right)_{2} \mathrm{WH}_{2}$, based on the results of theoretical calculations $^{2}$ on bent metallocene derivatives and supported by numerous structural and spectroscopic studies, ${ }^{3}$ is shown in Figure 1 . The $2 \mathrm{a}_{1}$ HOMO is a tungsten-localised lateral orbital that interacts minimally with the two hydride ligands, i.e. the orbital containing the tungsten 'lone pair'. Thus, protonation according to orbital control would be expected to proceed by path (a) giving the lateral $\left[{ }^{2} \mathrm{H}_{1}\right]$-isotopomer, $\left[\left(\mathrm{C}_{5} \mathrm{Me}_{5}\right)_{2} \mathrm{~W}(\mathrm{H})(\mathrm{H})(\mathrm{D})\right]^{+}$. Observation of the central $\left[{ }^{2} \mathrm{H}_{1}\right]-$ isotopomer, $\left[\left(\mathrm{C}_{5} \mathrm{Me}_{5}\right)_{2} \mathrm{~W}(\mathrm{H})(\mathrm{D})(\mathrm{H})\right]^{+}$, which arises by attack along the pseudo- $C_{2}$ axis, indicates a more subtle situation, however. Since there is no occupied, metal-based, central orbital, path (b) may be ruled out as a dominant mechanistic pathway. If the tungsten-hydride bonds are polarized substantially towards $\mathrm{W}-\mathrm{H}^{\delta-}$, the alternative protonation pathways, (c) and (d), should be particularly likely. Thus, protonation may be subject to charge control (i.e. $\mathrm{H}^{+}$attack at the $\mathrm{W}-\mathrm{H}^{\delta-}$ bond) rather than orbital control ( $\mathrm{H}^{+}$attack at the HOMO) ${ }^{4}$ Protonation of a single tungsten-hydrogen bond of $\left(\mathrm{C}_{5} \mathrm{Me}_{5}\right)_{2} \mathrm{WH}_{2}$ would thus proceed through a species that

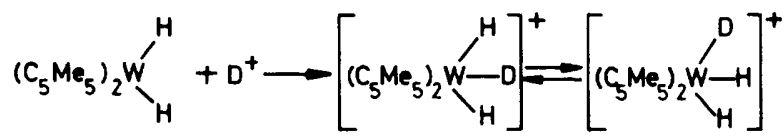


(a)

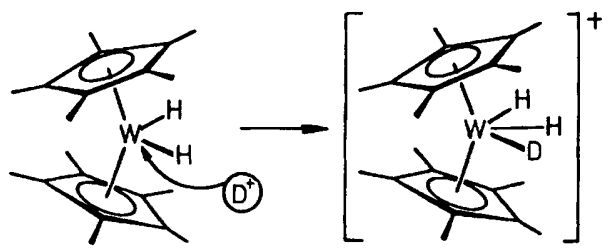

(b)

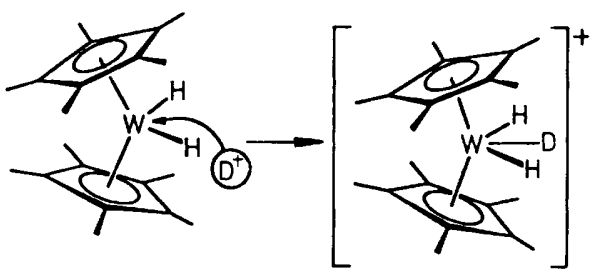

(c)
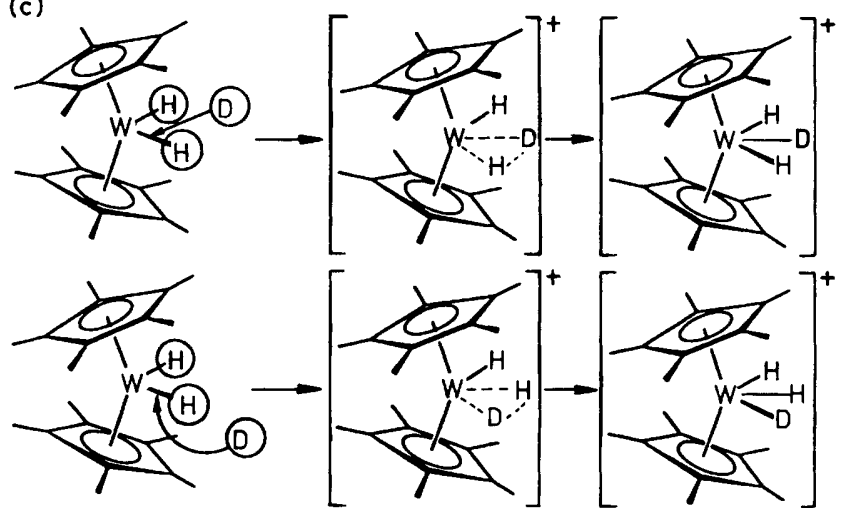

(d)

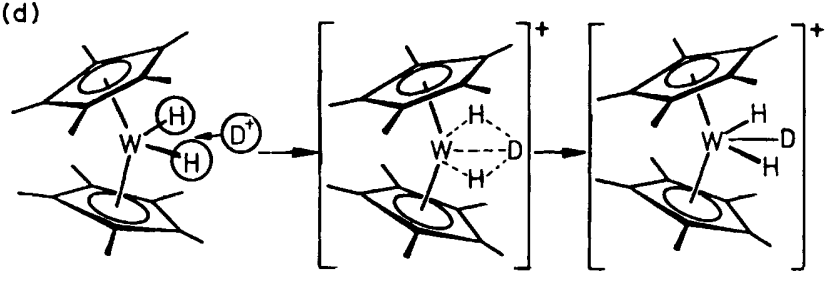

Scheme 1. Possible pathways for protonation of $\left(\mathrm{C}_{5} \mathrm{Me}_{5}\right)_{2} \mathrm{WH}_{2}$. (a) Electrophilic attack at a lateral, metal-based orbital; (b) electrophilic attack at a central, metal-based orbital; (c) central and lateral electrophilic attack at one of the hydride ligands; (d) central electrophilic attack at both the hydride ligands.

closely resembles (or may, in fact, be) the dihydrogen-hydride cation, $\left[\left(\mathrm{C}_{5} \mathrm{Me}_{5}\right)_{2} \mathrm{~W}\left(\eta^{2}-\mathrm{H}_{2}\right) \mathrm{H}\right]^{+}, 5$ which subsequently collapses to the trihydride cation. An analogous sequence for protonation of the $\mathrm{M}-\mathrm{H}$ bonds of the $\mathrm{d}^{0}$ complex $\mathrm{Re}\left(\mathrm{PR}_{3}\right)_{2} \mathrm{H}_{7}{ }^{6}$ and $\mathrm{d}^{6}$ complex $\left(\eta^{5}-\mathrm{C}_{5} \mathrm{H}_{5}\right)\left(\mathrm{Me}_{2} \mathrm{PCH}_{2} \mathrm{CH}_{2} \mathrm{PMe}_{2}\right) \mathrm{RuH}^{7}$ have recently been discussed.

Protonation of a single $\mathrm{W}-\mathrm{H}$ bond of $\left(\mathrm{C}_{5} \mathrm{Me}_{5}\right)_{2} \mathrm{WH}_{2}$ from the 'inside' of the $\mathrm{H}-\mathrm{W}-\mathrm{H}$ angle, rather than from a lateral position could possibly be strongly preferred; however, the factors dicatating such a preference are not obvious. Alternatively, it could be argued that the preferential $(\geqslant c a .20: 1)$ central protonation is a consequence of the interaction of the proton with both hydride ligands [pathway (d)], thus proceeding through a species that closely resembles (or may, in fact, be) the trihydrogen cation, $\left[\left(\mathrm{C}_{5} \mathrm{Me}_{5}\right)_{2} \mathrm{~W}\left(\eta^{3}-\mathrm{H}_{3}\right)\right]^{+}$, which subsequently collapses to the trihydride cation. The rather acute $\left(\mathrm{ca} .75^{\circ}\right) \mathrm{H}-\mathrm{W}-\mathrm{H}$ angle simultaneously offers both
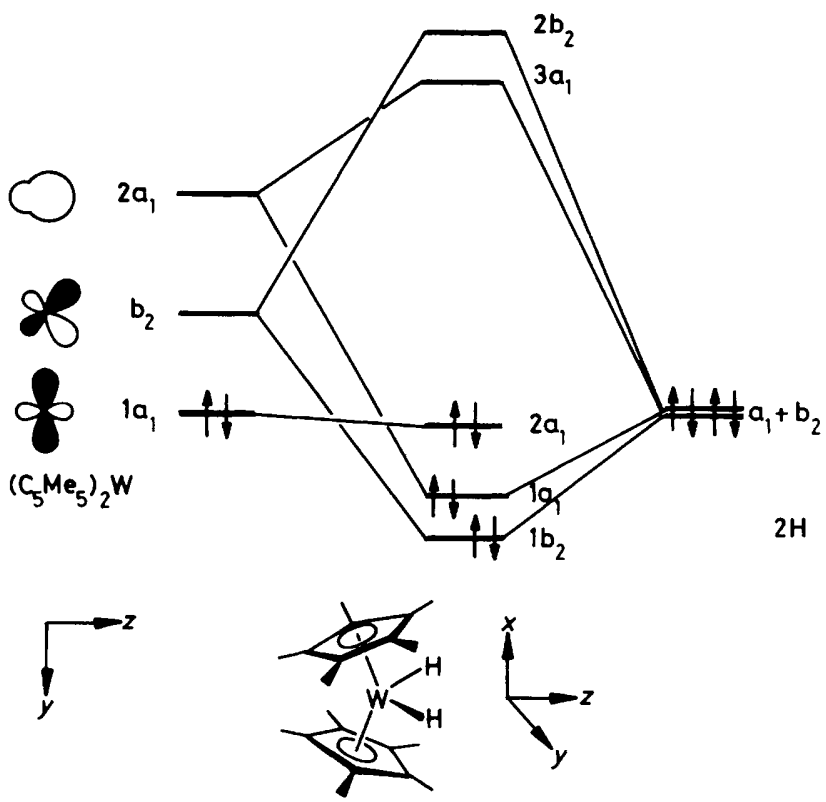

Figure 1. A qualitative $\mathrm{MO}$ diagram for $\left(\mathrm{C}_{5} \mathrm{Me}_{5}\right)_{2} \mathrm{WH}_{2}$

hydrides to electrophilic attack. A trihydrogen adduct has recently been invoked to account for the unusual n.m.r. behaviour for $\left[\left(\eta^{5}-\mathrm{C}_{5} \mathrm{H}_{5}\right)\left(\mathrm{PMe}_{3}\right) \operatorname{Ir}\left(\eta^{3}-\mathrm{H}_{3}\right)\right]^{+} .8 \mathrm{An}$ equivalent molecular orbital picture is that attack occurs at the second highest occupied molecular orbital (SHOMO), that of $1 a_{1}$ symmetry.

In contrast, treatment of $\left(\mathrm{C}_{5} \mathrm{Me}_{5}\right)_{2} \mathrm{~W}\left(\mathrm{CH}_{3}\right)_{2}$ with $\mathrm{HBF}_{4} \cdot \mathrm{Et}_{2} \mathrm{O}$ leads to oxidation to the radical cation, $\left[\left(\mathrm{C}_{5} \mathrm{Me}_{5}\right)_{2} \mathrm{~W}\left(\mathrm{CH}_{3}\right)_{2}\right]^{+}$, rather than simple protonation. ${ }^{9}$ This oxidation sequence may proceed by initial attack of $\mathrm{H}^{+}$at the tungsten centre, rather than at the $\mathrm{W}-\mathrm{CH}_{3}$ bond(s), the latter being less favoured relative to attack at $\mathrm{W}-\mathrm{H}$. $\dagger$

Kinetic analysis of ${ }^{1} \mathrm{H}$ n.m.r. data over a period of hours clearly reveals that $\left[\left(\mathrm{C}_{5} \mathrm{Me}_{5}\right)_{2} \mathrm{~W}(\mathrm{H})(\mathrm{H})(\mathrm{D})\right]^{+}$builds up in concentration, and does so faster than the overall conversion of the $\left[{ }^{2} \mathrm{H}_{1}\right]$ isotopomer $\left[\left(\mathrm{C}_{5} \mathrm{Me}_{5}\right)_{2} \mathrm{WH}_{2} \mathrm{D}\right]^{+}$to the $\left[{ }^{2} \mathrm{H}_{2}\right]-$ isotopomer, $\left[\left(\mathrm{C}_{5} \mathrm{Me}_{5}\right)_{2} \mathrm{WHD}_{2}\right]^{+}$, and the $\left[{ }^{2} \mathrm{H}_{3}\right]$-isotopomer, $\left[\left(\mathrm{C}_{5} \mathrm{Me}_{5}\right)_{2} \mathrm{WD}_{3}\right]^{+}$. This observation demonstrates that there must be an additional pathway for the direct intramolecular interconversion of the two $\left[{ }^{2} \mathrm{H}_{1}\right]$-isotopomers which does not involve a deprotonation mechanism, i.e. reaction (3). A possible direct pathway for the intramolecular exchange would involve pseudorotation out of the equatorial plane of the bent sandwich structure; however, we are not aware of a precedent for such a process. More likely mechanisms include (i) the intermediacy of a dihydrogen adduct which rotates, (ii) the intermediacy of a (closed) trihydrogen adduct ${ }^{10}$ which rotates, and (iii) migration of the hydride ligand to the $\mathrm{C}_{5} \mathrm{Me}_{5}$ ligand to give an $\eta^{4}$-diene intermediate, $\left(\mathrm{C}_{5} \mathrm{Me}_{5}\right)\left(\eta^{4}\right.$ $\mathrm{C}_{5} \mathrm{Me}_{5} \mathrm{H}$ )WHD $]^{+}$, followed by a 'Tarzan' type swing over the deuterium, and return to the metal centre.

$\left[\left(\mathrm{C}_{5} \mathrm{Me}_{5}\right)_{2} \mathrm{~W}(\mathrm{H})(\mathrm{D})(\mathrm{H})\right]^{+}$ $\rightleftarrows\left[\left(\mathrm{C}_{5} \mathrm{Me}_{5}\right)_{2} \mathrm{~W}(\mathrm{H})(\mathrm{H})(\mathrm{D})\right]^{+}$

† The greater propensity for attack at $\mathrm{W}-\mathrm{H}$ vs. $\mathrm{W}-\mathrm{CH}_{3}$ may be ascribed to the more favourable three-centre bonding involving the nondirectional $\mathrm{s}$ valence orbital of $\mathrm{H}$ relative to the highly directional $\mathrm{sp}^{3}$ orbital of the methyl group. 
We thank Professor Bruce Bursten for helpful discussions. This work was supported by the National Science Foundation (Grant No. CHE-8600875) and by Shell Companies Foundation, which are gratefully acknowledged. G. P. acknowledges support through a NATO Postdoctoral Fellowship administered through the S.E.R.C. (U.K.).

Received, 7th June 1988; Com. 8/02277A

\section{References}

1 F. G. N. Cloke, J. C. Green, M. L. H. Green, and C. P. Morley, J. Chem. Soc., Chem. Commun., 1985, 945; G. Parkin and J. E. Bercaw, Polyhedron, 1988, 7, 2053.

2 J. W. Lauher and R. Hoffmann, J. Am. Chem. Soc., 1976, 98, 1729; J. L. Petersen, D. L. Lichtenberger, R. F. Fenske, and L. F. Dahl, ibid., 1975, 97, 6433; H. H. Brintzinger, L. L. Lohr, Jr., and K. L. Tang Wong, ibid., 1975, 97, 5146; H. H. Brintzinger and L. S. Bartell, ibid., 1970, 92, 1105.

3 J. C. Green, M. L. H. Green, and C. K. Prout, J. Chem. Soc., Chem. Commun., 1972, 421; (b) J. L. Petersen and L. F. Dahl, J. Am. Chem. Soc., 1974, 96, 2248; 1975, 97, 6416; 1975, 97, 6422;
J. C. Green, S. E. Jackson, and B. Higginson, J. Chem. Soc., Dalton Trans., 1975, 403; A. J. Schultz, K. L. Stearley, J. M. Williams, R. Mink, and G. D. Stucky, Inorg. Chem., 1977, 16, 3303.

4 Theoretical calculations have demonstrated that the protonation of $\left[\left(\mathrm{C}_{5} \mathrm{H}_{5}\right) \mathrm{Fe}(\mathrm{CO})_{2}\right]_{2}(\mu-\mathrm{CO})\left(\mu-\mathrm{CH}_{2}\right)$ at the methylene ligand and not the $\mathrm{Fe}-\mathrm{Fe}$ bond is charge and not orbital controlled, B. E. Bursten and R. H. Cayton, J. Am. Chem. Soc., 1987, 109, 6053. 5 Dihydrogen complexes have been recently reviewed, G. J. Kubas, Acc. Chem. Res., 1988, 21, 120.

6 X. L. R. Fontaine, E. H. Fowles, and B. L. Shaw, J. Chem. Soc., Chem. Commun., 1988, 482.

7 M. S. Chinn and D. M. Heinekey, J. Am. Chem. Soc., 1987, 109, 5865.

8 D. M. Heinekey, N. G. Payne, and G. K. Schulte, J. Am. Chem. Soc., 1988, 110, 2303; B. Chaudret, personal communication.

9 Similarly, $\mathrm{HBF}_{4}$ oxidises $\left(\mathrm{C}_{5} \mathrm{Me}_{5}\right)_{2} \mathrm{Mo}\left(\mathrm{CH}_{3}\right)_{2}$ to $\left[\left(\mathrm{C}_{5} \mathrm{Me}_{5}\right)_{2}-\right.$ $\left.\mathrm{Mo}\left(\mathrm{CH}_{3}\right)_{2}\right]^{+}$. J. C. Green, M. L. H. Green, and C. P. Morley, J. Organomet. Chem., 1982, 233, C4.

10 Closed trihydrogen species have been studied theoretically to account for the observed exchange processes in bis-dihydrogen complexes. J. K. Burdett, J. R. Phillips, M. R. Pourian, M. Poliakoff, J. J. Turner, and R. Upmacis, Inorg. Chem., 1987, 26, 3054. 